\title{
Carcass characteristics and meat quality of lambs fed high levels of spineless cactus in the diet
}

\author{
S.B.L. Bezerra1, R.M.L. Véras ${ }^{2}$, A.M.V. Batista ${ }^{1}$, A. Guim¹, M.V. Maciel ${ }^{3}$, D.B. Cardoso², D. \\ M. Lima Júnior ${ }^{4 \prime} \&$ F.F.R. Carvalho ${ }^{1}$ \\ ${ }^{1}$ Rural Federal University of Pernambuco, Dom Manoel de Medeiros Street, s/n, Dois Irmãos, 52171-900, Recife, \\ Pernambuco, Brazil \\ ${ }^{2}$ Federal University of Agreste of Pernambuco, Bom Pastor Street, s/n, Boa Vista, 55292-270, Garanhuns, \\ Pernambuco, Brazil \\ ${ }^{3}$ Federal University of Amazonas, Campus Parintins, 69152-470, Parintins, Amazonas, Brazil \\ ${ }^{4}$ Federal University of Alagoas, Campus Arapiraca, Manoel Severino Barbosa Street, s/n, Bom Sucesso, Arapiraca, \\ Alagoas, 57309-005, Brazil
}

(Received 18 September 2020; Accepted 5 February 2021; Published 7 July 2021)

\begin{abstract}
Copyright resides with the authors in terms of the Creative Commons Attribution 4.0 South African Licence.
See: http://creativecommons.org/licenses/by/4.0/za

Condition of use: The user may copy, distribute, transmit and adapt the work, but must recognise the authors and the South African Journal of Animal Science.
\end{abstract}

\begin{abstract}
The objective was to evaluate the effect of increasing the dietary inclusion of spineless cactus (Nopalea cochenillifera Salm Dyck) on the carcass characteristics and meat quality of confined lambs. Thirtytwo male Santa Inês lambs with an average age of 140 days and an initial body weight of $20.4 \pm 2.60 \mathrm{~kg}$ were used in this study. The lambs were housed in individual stalls for 70 days and individually fed a ration with spineless cactus included at $0,241,519$, or $753 \mathrm{~g} / \mathrm{kg}$ of dry matter (DM). The lambs were slaughtered, and characteristics of the carcass and meat were recorded and analysed. Inclusion of spineless cactus had a quadratic effect on the bodyweight at slaughter and on the empty bodyweight of the lambs. The inclusion of $500 \mathrm{~g} / \mathrm{kg}$ of spineless cactus provided the highest predicted cold carcass weight $(16.03 \mathrm{~kg})$. There was a quadratic effect of the inclusion of spineless cactus on the weight of meat cuts and leg composition of lambs. The inclusion of spineless cactus did not influence $\mathrm{pH}$, tenderness, and water-retention capacity of the meat. However, the intramuscular fat content increased $1 \mathrm{mg}$ for every $10 \mathrm{~g} / \mathrm{kg}$ inclusion of spineless cactus in the diet. Quadratic effects were observed of the inclusion of spineless cactus on the weights of the liver, heart, rumen, blood, skin and internal fat of the lambs. Up to $500 \mathrm{~g} / \mathrm{kg}$ of spineless cactus could be included in the diet of confined lambs.
\end{abstract}

Keywords: lamb meat, non-carcass constituents, Nopalea cochenillifera Salm Dyck, tissue composition "Corresponding author: juniorzootec@yahoo.com.br

\section{Introduction}

The largest flocks of sheep are found in tropical areas (FAO, 2020), feeding mainly on native pasture. In these regions, variations in rainfall impose severe food restrictions on animals during drought (Salem, 2010). Therefore, the use of xerophyte forages, such as spineless cactus, appears to be a feed alternative for these flocks.

Spineless cactus produces $10-30$ tons $\mathrm{DM} / \mathrm{ha} /$ harvest. It has a proximate composition $(\mathrm{g} / \mathrm{kg}$, mean (SD)) of 108.7 (9.4) DM, 50.9 (6.2) crude protein, 244.7 (13.6) neutral detergent fibre, and 545.7 (10.7) nonfibrous carbohydrates (Lins et al., 2016; Oliveira et al., 2018; Silva et al., 2019). Owing to high ruminal degradability, estimated to be $701.1 \pm 8.4 \mathrm{~g} / \mathrm{kg}$ DM (Batista et al., 2009), spineless cactus is usually fed with other roughage to optimise the intake and digestibility of nutrients by ruminants (Siqueira et al., 2017; Maciel et al., 2019). However, it is necessary to establish the maximum level of inclusion of spineless cactus that improves the carcass characteristics and meat quality of sheep in confinement. In the diet of lambs for fattening, Cardoso et al. (2019) found a linear increase in weight gain and improvement in feed conversion with the inclusion of $450 \mathrm{~g} / \mathrm{kg}$ of spineless cactus. Similarly, Moura et al. (2020) found a positive linear effect of the inclusion of $600 \mathrm{~g} / \mathrm{kg}$ of spineless cactus on carcass fat covering, without negative effects on cold carcass weight and physicochemical characteristics of lamb meat. There is a need to study even higher 
levels - greater than $600 \mathrm{~g} / \mathrm{kg}$ - of spineless cactus in the diet of lambs being fattened for slaughter. Therefore, the effects of rising levels of inclusion of spineless cactus on the carcass characteristics and meat quality of lambs in feedlots were evaluated in this study.

\section{Material and Methods}

All procedures had been authorised by the Ethics Committee on the Use of Animals (CEUA), Rural Federal University of Pernambuco (licence 23082.012176/2014-51). The experiment was carried out at coordinates $8^{\circ} 04$ '03" S and $34^{\circ} 55$ '00" W with an average temperature of $25.8 \pm 2.8^{\circ} \mathrm{C}$ and annual precipitation of $18 \mathrm{~cm}$.

Thirty-two male Santa Inês lambs with an average age of 140 days and an initial body weight of $20.4 \pm$ $2.60 \mathrm{~kg}$ were allocated to individual stalls with feeders and drinking fountains. Water was available ad libitum. Initially, 14 days were provided for adaptation to the diets, facilities, and management. During adaptation, the animals were treated against endo- and ectoparasites. After adaptation, the animals were weighed and randomly assigned to one of four dietary treatments. The diets contained $0,241,519$, and 753 $\mathrm{g} / \mathrm{kg}$ spineless cactus on a DM basis. The feeding period was 56 days.

The treatment diets were formulated to meet the weight gain requirement of $200 \mathrm{~g} /$ day of growing lambs (NRC, 2007). The diets were composed of spineless cactus (Nopalea cochenillifera Salm Dyck), Tifton grass hay (Cynodon spp.), soybean meal, crushed corn grain, mineral salt, and urea (Tables 1 and 2). The spineless cactus was chopped in a disintegrating machine and the Tifton 85 grass hay was crushed in a forage machine with a $13 \mathrm{~mm}$ sieve. The rations were supplied as a complete mixture twice a day, with $60 \%$ being offered in the morning and $40 \%$ in the afternoon. The leftovers were weighed daily to adjust the supply so that it allowed approximately $15 \%$ of leftovers.

Table 1 Chemical composition of ingredients of experimental diets fed to lambs

\begin{tabular}{lcccc}
\hline Nutrient & Tifton hay 85 & Spineless cactus & Corn grain & Soybean meal \\
\hline Dry matter (DM), g/kg & 918.17 & 100.00 & 881.69 & 890.69 \\
Organic matter, g/kg DM & 962.60 & 812.70 & 919.40 & 925.60 \\
Mineral matter, g/kg DM & 17.40 & 187.30 & 80.60 & 74.20 \\
Ether extract, g/kg DM & 17.10 & 16.90 & 41.60 & 13.80 \\
Crude protein, g/kg DM & 76.00 & 58.60 & 90.90 & 526.80 \\
Neutral detergent fibre, g/kg DM & 745.10 & 259.70 & 98.50 & 143.80 \\
Acid detergent fibre, g/kg DM & 356.40 & 150.80 & 76.80 & 25.00 \\
Non-fibre carbohydrates, g/kg DM & 144.40 & 477.50 & 688.40 & 241.40 \\
\end{tabular}

Food offered to each animal and the leftovers were recorded weekly. All collected material generated individual composite samples, which were weighed, identified, pre-dried in an oven at $55^{\circ} \mathrm{C}$ for 72 hours, ground in a mill with 1-mm sieve screens and stored in polyethylene pots.

AOAC (2000) methodologies were used to determine DM (method 934.01), mineral matter (method 942.05), crude protein (CP) (method 968.06), and ether extract (EE) (method 920.39), the contents of the feed and leftovers. Neutral detergent fibre (NDF) and acid detergent fibre (ADF) was assessed according to Van Soest et al. (1991). Protein corrections followed Licitra et al. (1996). For quantification of total carbohydrates (TC), the equation:

$$
\mathrm{TC}=100-(\% \mathrm{CP}+\% \mathrm{EE}+\% \text { Ash })
$$

was used and the contents of non-fibrous carbohydrates in the diet was calculated as:

$$
\mathrm{NFC}=100 \%-((\mathrm{CP} \%-\mathrm{CP} \% \text { derived from urea }+\% \text { urea })+\mathrm{NDF} \%+\mathrm{EE} \%+\text { Ash\% })(\text { Hall, } 2000) .
$$


Table 2 Ingredients and chemical composition of diets containing increasing levels of spineless cactus

\begin{tabular}{|c|c|c|c|c|}
\hline \multirow{2}{*}{ Ingredients } & \multicolumn{4}{|c|}{ Inclusion level of spineless cactus } \\
\hline & $0 \mathrm{~g} / \mathrm{kg}$ & $241 \mathrm{~g} / \mathrm{kg}$ & $519 \mathrm{~g} / \mathrm{kg}$ & $753 \mathrm{~g} / \mathrm{kg}$ \\
\hline Tifton hay & 774.0 & 530.0 & 253.0 & 0.0 \\
\hline Spineless cactus & 0.0 & 241.0 & 519.0 & 753.0 \\
\hline Corn grain & 89.2 & 67.6 & 44.9 & 24.3 \\
\hline Soybean meal & 121.6 & 146.0 & 167.8 & 206.2 \\
\hline Mineral mix ${ }^{1}$ & 5.1 & 5.1 & 5.1 & 5.5 \\
\hline Urea & 10.1 & 10.3 & 10.2 & 11.0 \\
\hline \multicolumn{5}{|l|}{ Chemical composition } \\
\hline Dry matter (DM), g/kg & 911.50 & 308.38 & 174.75 & 128.11 \\
\hline Organic matter, g/kg DM & 939.62 & 903.30 & 861.91 & 825.17 \\
\hline Crude protein, g/kg DM & 159.27 & 166.49 & 170.63 & 185.76 \\
\hline Ether extract, g/kg DM & 18.62 & 17.97 & 17.28 & 16.58 \\
\hline Neutral detergent fibre, g/kg DM & 602.98 & 484,81 & 351,86 & 227.58 \\
\hline Acid detergent fibre, $\mathrm{g} / \mathrm{kg} \mathrm{DM}$ & 285.74 & 233.90 & 176.09 & 120.57 \\
\hline Non-fibre carbohydrates, g/kg DM & 202.53 & 273.53 & 355.80 & 426.08 \\
\hline Total digestible nutrients & 721.10 & 753.60 & 731.80 & 670.50 \\
\hline Metabolisable energy, Mcal/kg DM & 2.60 & 2.71 & 2.64 & 2.42 \\
\hline
\end{tabular}

${ }^{1}$ Provided per kg: calcium: $140 \mathrm{~g}$, phosphorus: $70 \mathrm{~g}$, magnesium: $1320 \mathrm{mg}$, iron: $2200 \mathrm{mg}$, cobalt: 140 mg, manganese: $3690 \mathrm{mg}$, zinc: $4700 \mathrm{mg}$, iodine: $61 \mathrm{mg}$, selenium: $45 \mathrm{mg}$, sulfur: $12 \mathrm{~g}$, sodium: $148 \mathrm{~g}$, fluorine: $700 \mathrm{mg}$

At the end of the 56-day feeding period, the animals were fasted for 16 hours. After that time, they were weighed again to obtain bodyweight at slaughter (BWS). The slaughtering process started with a stunning brain concussion, followed by bleeding from the fission of the carotid arteries and jugular veins (Brasil, 2000). The blood was collected in a tarred container and then weighed. The carcass was and eviscerated, skinned, the head, feet, and tail were removed, and hot carcass weight (HCW) was recorded. The gastrointestinal tract was weighed full and empty to determine the empty bodyweight (EBW). The weight of the contents of the gastrointestinal tract was quantified as the difference between the weights of the full and empty tract. The non-constituent components of the carcass were separated into organs, viscera and slaughter by-products (Bezerra et al., 2010) and weighed.

The carcasses were hung individually on hooks by the tarsus-metatarsal joints and refrigerated at $4{ }^{\circ} \mathrm{C}$ for 24 hours. After cooling, each carcass were weighed again to determine the cold carcass weight (CCW) and cooling loss was calculated as:

$$
\mathrm{CL}(\%)=(\mathrm{CCW}-\mathrm{HCW} / \mathrm{HCW}) \times 100 \text { (Gonzaga Neto et al., 2006) }
$$

Subsequently, yields of hot $(\mathrm{HCY})$ and cold carcass $(\mathrm{CCY})$ were calculated relative to BWS, and the true yield was calculated as:

$$
\text { TY }(\%)=\text { HCW/EBW } \times 100 \text { (Cezar \& Souza, 2007) }
$$

Morphometric measurements were made on the cold carcass. The carcass compactness index $(\mathrm{CCl})$ was calculated as:

$$
\mathrm{CCl}(\mathrm{kg} / \mathrm{cm})=\mathrm{CCW} / \text { internal length carcass (Cezar \& Souza, 2007) }
$$

Each cold carcass was cut in half and the half-carcasses were weighed. The left half-carcass was divided into six commercial cuts (Cezar \& Sousa (2007), namely shoulder, leg, loin, rib, belly, and neck, which were weighed individually, and their weights recorded. Owing to the weight loss, because of the evaporation and exudation processes that the cuts undergo during shredding, the yields were estimated in relation to the reconstituted CCW, which is obtained from the weight of all the cuts in the half-carcass. The 
legs and loins of each animal were identified, vacuum-packed in polyethylene bags and frozen in a freezer ($18^{\circ} \mathrm{C}$ ) to assess tissue composition and physical-chemical analysis.

the left half of the carcass was split between the 12th and 13th thoracic vertebrae to measure the Longissimus muscle area. After the Longissimus dorsi muscle had been exposed, a transparent plastic film was placed on it, the outline of the muscle was traced, and its area was later measured with a digital planimeter.

The loins (Longissimus dorsi muscle) were used for physical-chemical analysis. The samples were removed from the freezer, and thawed at $4{ }^{\circ} \mathrm{C}$ for 18 hours. Then the colour of the muscle was determined with a Minolta colorimeter (Chroma Meter CR-400, Konica Minolta Sensing Americas, Inc., Ramsey, New Jersey, USA) operating in the CIELAB system. After the Longissimus dorsi had been exposed to air for 30 minutes under refrigeration at $4{ }^{\circ} \mathrm{C}$ to allow the superficial oxygenation of the myoglobin, three measurements were made at different points of the muscle, noting the average values (Ramos \& Gomide (2009).

Ten-gram samples of the muscle were obtained. Each sample was crushed and diluted with $150 \mathrm{ml}$ distilled water and stirred until the particles were suspended uniformly, then the $\mathrm{pH}$ was measured.

The samples, which were composed of slices approximately $1.5 \mathrm{~cm}$ thick, $3.0 \mathrm{~cm}$ long and $2.5 \mathrm{~cm}$ wide, were weighed, distributed in a container covered with aluminium foil, then roasted in a preheated oven at $200{ }^{\circ} \mathrm{C}$ until they reached $70{ }^{\circ} \mathrm{C}$ in the geometric centre. Then the samples were cooled to room temperature and weighed again. The losses during cooking were calculated as the difference in weight of the samples before and after being roasted and were expressed as a percentage (Duckett et al., 1998).

Shear force was measured (Ramos \& Gomide, 2009) using three cylindrical samples of the roasted meat, $1.27 \mathrm{~cm}$ in diameter, taken parallel to the direction of the muscle fibres. The force required to cut each cylinder was measured with Warner-Bratzler shear force (GR Electric Manufacturing, Manhattan, Kansas, USA) with the result expressed as newtons (N).

Water-holding capacity (WHC) was determined by placing a meat samples weighing approximately 30 grams were placed between two pieces of weighed filter paper and pressing it for five minutes with a $3.4 \mathrm{~kg}$ weight. Then, the samples were removed, and the papers were weighed again. The WHC consisted of the difference between the weights of the filter paper after and before pressing, with the difference being expressed as a percentage of the sample weight (Sierra, 1973).

Dissection of the leg (see Cesar \& Souza, 2007) to determine tissue composition started with its removal from the freezer and thawing the cut for 24 hours at $4{ }^{\circ} \mathrm{C}$. Subcutaneous fat (located between the skin and the masses of muscle tissue) was removed, intermuscular fat, muscles (after removal of all adhered fat), bones (ischium, ilium, pubis, sacrum, femur, tibia, fibula, calcaneus, and metatarsus) and other tissues (tendons, lymph nodes, nerves, and blood vessels) were weighed, and the percentage of tissue components was calculated based on the reconstituted weight of the leg, because of weight loss from evaporation and exudation. The ratios of muscle to bone and of muscle to fat were calculated. The five main muscles surrounding the femur (Biceps femoris, Semimembranosus, Semitendinosus, Quadriceps femoris, and Adductor) were removed in full, the length of the femur $(\mathrm{cm})$ was measured and the leg muscle index was calculated (Purchas et al., 1991):

$$
\mathrm{LMI}=\sqrt{\frac{\mathrm{P} 5 \mathrm{M}}{\mathrm{LF}}} / \mathrm{LF}
$$

where: $L M I=$ leg muscle index, P5M = weight of the five muscles $(g)$, and LF = length of the femur $(\mathrm{cm})$.

The chemical composition of the Semimembranosus muscle was determined after dissection of the leg. The samples were homogenised in a blender and then lyophilised to assess moisture, CP, EE, and ash (AOAC, 2000).

The analysis of variance was conducted using a randomised block design according to this model:

$$
Y_{i j}=\mu+B_{i}+T_{j}+e_{i j}
$$

where: $Y_{i j}=$ a response variable, $B_{i}=$ the effect if the ith block, $T_{j}=$ the effect of the jth treatment, and $e_{i j}=$ the residual error.

Treatments were compared by decomposing the sum of squares into orthogonal contrasts. Contrast $A$ compared the diet containing $0 \mathrm{~g} / \mathrm{kg}$ spineless cactus with the average of the diets containing cactus. Contrasts $B$ and $C$ evaluated the linear and quadratic effects of the levels of spineless cactus in the diets. SAS software version 9.1 (SAS Institute, Inc., Cary, North Carolina, USA) was used to analyse the data.

\section{Results and Discussion}


The digestible organic matter intake (DOM) intake, metabolisable energy (ME) and digestible crude protein $(\mathrm{DCP})$ intake behaved in a quadratic effect $(P<0.01)$ owing to the increasing inclusion of spineless cactus in the diet (Table 3 ). With the exceptions of gut fill and CCY, these quadratic effects implied a maximum value that was intermediate relative to the dietary treatments. The control was the most fibrous and produced the highest amount of gut fill. Cold carcass yield was maximised for lamb. fed $753 \mathrm{~g} / \mathrm{kg}$ spineless cactus. The inclusion of spineless cactus in the diet also produced quadratic responses $(P<0.01)$ for EBW, CCW and CCY.

Table 3 Intake of nutrients, weight and carcass yields of lambs fed increasing levels of spineless cactus

\begin{tabular}{|c|c|c|c|c|c|c|c|c|}
\hline & \multicolumn{4}{|c|}{ Inclusion of spineless cactus, $\mathrm{g} / \mathrm{kg}$} & \multirow{2}{*}{ SE } & \multicolumn{3}{|c|}{ Contrast P-values } \\
\hline & 0 & 241 & 519 & 753 & & $A$ & $\mathrm{~B}$ & $\mathrm{C}$ \\
\hline DOM intake, g/d & 620.2 & 934.4 & 926.8 & 733.3 & 65.50 & $<0.05$ & $<0.05$ & $<0.01$ \\
\hline DCP intake, g/d & 127.0 & 187.4 & 172.5 & 141.8 & 10.17 & $<0.05$ & ns & $<0.01$ \\
\hline ME intake Mcal/kg & 2.85 & 4.20 & 4.20 & 3.19 & 0.56 & $<0.05$ & ns & $<0.01$ \\
\hline Slaughter weight, kg & 27.2 & 32.9 & 32.6 & 28.9 & 1.19 & $<0.05$ & ns & $<0.01$ \\
\hline Empty body weight, $\mathrm{kg}$ & 20.7 & 27.6 & 28.1 & 25.9 & 1.04 & $<0.05$ & $<0.01$ & $<0.01$ \\
\hline Gut fill, kg & 6.16 & 5.25 & 4.89 & 2.99 & 0.19 & $<0.05$ & $<0.01$ & $<0.05$ \\
\hline Hot carcass weight, kg & 11.3 & 15.3 & 15.6 & 14.4 & 0.63 & $<0.05$ & $<0.01$ & $<0.01$ \\
\hline Cold carcass weight, $\mathrm{kg}$ & 10.9 & 14.9 & 15.3 & 14.0 & 0.60 & $<0.05$ & $<0.01$ & $<0.01$ \\
\hline Cooling loss, \% & 3.7 & 2.9 & 2.8 & 2.7 & 0.23 & $<0.05$ & ns & ns \\
\hline Hot carcass yield, \% & 41.9 & 46.5 & 47.5 & 49.8 & 0.67 & $<0.05$ & $<0.05$ & ns \\
\hline Cold carcass yield, \% & 40.5 & 45.2 & 46.2 & 48.5 & 0.65 & $<0.05$ & $<0.05$ & $<0.05$ \\
\hline Biological yield, \% & 54.3 & 54.6 & 55.9 & 55.5 & 0.68 & ns & ns & ns \\
\hline $\begin{array}{l}\text { Longissimus muscle area, } \\
\mathrm{cm}^{2}\end{array}$ & 7.1 & 10.4 & 10.3 & 9.7 & 0.53 & $<0.05$ & $<0.01$ & $<0.01$ \\
\hline Carcass compactness, $\mathrm{kglcm}$ & 0.18 & 0.24 & 0.25 & 0.23 & 0.01 & $<0.05$ & $<0.01$ & $<0.01$ \\
\hline
\end{tabular}

DOM: digestible organic matter, DCP: digestible crude protein, ME: metabolisable energy A: control $(0 \mathrm{~g} / \mathrm{kg}$ spineless cactus) versus treatments that contained spineless cactus, B: linear effect of spineless cactus inclusion, C: quadratic effect of spineless cactus inclusion

All meat cuts showed a quadratic response $(P<0.01)$ to the level of spineless cactus included in the diet before slaughter (Table 4). The maximum weights of the individual cuts were from lambs fed the intermediate levels of spineless cactus, namely $241 \mathrm{~g} / \mathrm{kg}$ and $519 \mathrm{~g} / \mathrm{kg}$. The inclusion of spineless cactus did not influence $(P>0.05)$ the percentages of the meat cuts in the carcasses except for the loin.

The leg represented about $34 \%$ of the CCW and the composition of this cut in muscle, fat, and bone was influenced $(P<0.01)$ by the inclusion of spineless cactus in the diet $($ Table 5$)$. the responses to the level of spineless cactus included in the diet were quadratic in the dissected leg, except for the percentage of muscle and the mass of other tissues. The percentages of muscle and fat were maximised, and the percentage of bones was minimised in the leg from lambs that were fed the intermediate levels of spineless cactus.

Inclusion of spineless cactus did not influence $(P>0.05)$ the lightness $\left(L^{*}\right)$, redness $\left(\mathrm{a}^{*}\right), \mathrm{pH}$ and shear force of the meat of the lambs (Table 6). However, it influenced the yellowness $\left(b^{*}\right)$ of the meat in a quadratic way $(P<0.05)$. This might be the result of the quadratic effect for the percentage of fat. Inclusion of spineless cactus had a quadratic influence $(P<0.05)$ on cooking loss from the meat. However, this effect seemed to be related to the inexplicably high value for lambs fed $519 \mathrm{~g} / \mathrm{kg}$ of spineless cactus. 
Table 4 Weight of meat cuts from lamb carcasses fed with increasing levels of spineless cactus

\begin{tabular}{|c|c|c|c|c|c|c|c|c|}
\hline \multirow{2}{*}{ Cut of meat } & \multicolumn{4}{|c|}{ Inclusion of spineless cactus, $\mathrm{g} / \mathrm{kg}$} & \multirow{2}{*}{ SE } & \multicolumn{3}{|c|}{ Contrast $P$-values } \\
\hline & 0 & 241 & 519 & 753 & & A & B & $\mathrm{C}$ \\
\hline Shoulder & 1.1 & 1.5 & 1.5 & 1.4 & 0.05 & $<0.01$ & $<0.01$ & $<0.01$ \\
\hline Neck & 0.5 & 0.7 & 0.8 & 0.7 & 0.05 & $<0.01$ & $<0.05$ & $<0.01$ \\
\hline Ribs & 0.9 & 1.2 & 1.3 & 1.2 & 0.06 & $<0.05$ & $<0.01$ & $<0.01$ \\
\hline Belly & 0.6 & 0.9 & 0.9 & 0.8 & 0.05 & $<0.05$ & $<0.05$ & $<0.01$ \\
\hline Leg & 1.9 & 2.6 & 2.6 & 2.4 & 0.09 & $<0.01$ & $<0.01$ & $<0.01$ \\
\hline Loin & 0.4 & 0.6 & 0.6 & 0.5 & 0.04 & $<0.01$ & $<0.05$ & $<0.01$ \\
\hline
\end{tabular}

A: control (0 g/kg spineless cactus) versus treatments that contained spineless cactus, B: linear effect of spineless cactus inclusion, C: quadratic effect of spineless cactus inclusion

Table 5 Tissue composition of the leg of lambs fed with increasing levels of spineless cactus

\begin{tabular}{|c|c|c|c|c|c|c|c|c|}
\hline \multirow{2}{*}{ Components } & \multicolumn{4}{|c|}{ Inclusion of spineless cactus, $\mathrm{g} / \mathrm{kg}$} & \multirow{2}{*}{ SE } & \multicolumn{3}{|c|}{ Contrast P-values } \\
\hline & 0 & 241 & 519 & 753 & & $A$ & $\mathrm{~B}$ & $\mathrm{C}$ \\
\hline Reconstituted leg, g & 1777 & 2432 & 2435 & 2268 & 92.95 & $<0.01$ & $<0.01$ & $<0.01$ \\
\hline Muscle, g & 1208 & 1642 & 1666 & 1509 & 67.60 & $<0.01$ & $<0.01$ & $<0.01$ \\
\hline Muscle, \% & 68.1 & 68.1 & 68.8 & 66.9 & 0.62 & ns & ns & ns \\
\hline Bones, $g$ & 406.5 & 496.0 & 482.8 & 484.3 & 11.88 & $<0.01$ & $<0.01$ & $<0.01$ \\
\hline Bones, \% & 23.4 & 20.8 & 20.1 & 21.5 & 0.66 & $<0.01$ & ns & $<0.01$ \\
\hline Fat, $g$ & 105.3 & 212.0 & 206.1 & 173.8 & 15.56 & $<0.01$ & $<0.01$ & $<0.01$ \\
\hline Fat, \% & 5.8 & 8.7 & 8.6 & 7.7 & 0.51 & $<0.01$ & $<0.05$ & $<0.01$ \\
\hline Other tissue, g & 50.3 & 58.5 & 60.0 & 86.3 & 6.65 & $<0.05$ & $<0.01$ & ns \\
\hline Other tissue, \% & 2.9 & 2.4 & 2.5 & 3.9 & 0.31 & $<0.05$ & $<0.05$ & $<0.01$ \\
\hline Muscle to bone ratio & 2.9 & 3.3 & 3.5 & 3.1 & 0.12 & $<0.05$ & ns & $<0.01$ \\
\hline Muscle to fat ratio & 12.7 & 8.3 & 8.1 & 8.9 & 0.87 & $<0.01$ & $<0.01$ & $<0.01$ \\
\hline Leg muscle index, $\mathrm{g} / \mathrm{cm}$ & 0.36 & 0.42 & 0.40 & 0.39 & 0.01 & $<0.05$ & ns & $<0.01$ \\
\hline
\end{tabular}

A: control (0 $\mathrm{g} / \mathrm{kg}$ spineless cactus) versus treatments that contained spineless cactus, B: linear effect of spineless cactus inclusion, C: quadratic effect of spineless cactus inclusion

Table 6 Physico-chemical characteristics of meat (Longissimus dorsi) from lambs fed increasing levels of spineless cactus

\begin{tabular}{|c|c|c|c|c|c|c|c|c|}
\hline & \multicolumn{4}{|c|}{ Inclusion of spineless cactus $(\mathrm{g} / \mathrm{kg})$} & \multirow{2}{*}{ SE } & \multicolumn{3}{|c|}{ Contrast $P$-values } \\
\hline & 0 & 241 & 519 & 753 & & $A$ & $\mathrm{~B}$ & C \\
\hline Lightness, L* & 37.8 & 37.6 & 38.6 & 36.8 & 0.57 & ns & ns & ns \\
\hline Redness, $\mathrm{a}^{*}$ & 14.2 & 13.6 & 13.1 & 13.6 & 0.29 & ns & ns & ns \\
\hline Yellowness, b* & 7.8 & 9.1 & 8.0 & 7.8 & 0.28 & $<0.05$ & ns & $<0.05$ \\
\hline $\mathrm{pH}$ & 5.1 & 4.8 & 4.7 & 4.8 & 0.11 & ns & ns & ns \\
\hline Shear force, $\mathrm{kg} / \mathrm{cm}^{2}$ & 14.7 & 15.7 & 15.7 & 16.7 & 1.13 & ns & ns & ns \\
\hline Cooking losses, \% & 32.3 & 31.0 & 39.9 & 30.6 & 1.41 & $<0.05$ & ns & $<0.05$ \\
\hline Water-holding capacity, \% & 33.8 & 34.7 & 33.6 & 33.5 & 0.79 & ns & ns & ns \\
\hline
\end{tabular}

A: control (0 g/kg spineless cactus) versus treatments that contained spineless cactus, B: linear effect of spineless cactus inclusion, C: quadratic effect of spineless cactus inclusion 
The inclusion of spineless cactus in the diet did not affect the moisture, protein, and mineral contents of lamb meat (Table 7). The EE content increased linearly $(P<0.01)$.

Table 7 Composition of meat (Semimembranosus) from lambs fed increasing levels of spineless cactus

\begin{tabular}{|c|c|c|c|c|c|c|c|c|}
\hline & \multicolumn{4}{|c|}{ Inclusion of spineless cactus (g/kg) } & \multirow{2}{*}{ SE } & \multicolumn{3}{|c|}{ Contrast $P$-values } \\
\hline & 0 & 241 & 519 & 753 & & A & B & C \\
\hline Moisture, \% & 76.5 & 75.8 & 75.4 & 75.3 & 0.51 & ns & ns & ns \\
\hline Ashes, \% & 1.2 & 1.4 & 1.3 & 1.4 & 0.10 & $\mathrm{~ns}$ & $\mathrm{~ns}$ & ns \\
\hline Ether extract, \% & 1.7 & 2.1 & 2.3 & 2.4 & 0.16 & $<0.01$ & $<0.01$ & ns \\
\hline Crude protein, \% & 17.7 & 18.1 & 18.2 & 18.2 & 0.42 & $\mathrm{~ns}$ & ns & $\mathrm{ns}$ \\
\hline
\end{tabular}

A: control ( $0 \mathrm{~g} / \mathrm{kg}$ spineless cactus) versus treatments that contained spineless cactus, B: linear effect of spineless cactus inclusion, C: quadratic effect of spineless cactus inclusion

The inclusion of spineless cactus resulted in quadratic effects $(P<0.01)$ on heart, spleen, kidney and liver weights (Table 8$)$. The highest liver weight $(0.59 \mathrm{~kg})$ was observed when the animals consumed 500 $\mathrm{g} / \mathrm{kg}$ of spineless cactus. Quadratic effects $(P<0.01)$ due to the level of spineless cactus in the diet were also detected for blood, skin, feet, head, and internal fat weights owing to the increasing inclusion of spineless cactus.

Table 8 Non-carcass components of lambs fed increasing levels of spineless cactus

\begin{tabular}{|c|c|c|c|c|c|c|c|c|}
\hline \multirow{2}{*}{ Component, kg } & \multicolumn{4}{|c|}{ Inclusion of spineless cactus $(\mathrm{g} / \mathrm{kg})$} & \multirow{2}{*}{ SE } & \multicolumn{3}{|c|}{ Contrast $P$-values } \\
\hline & 0 & 241 & 519 & 753 & & A & B & C \\
\hline Heart & 0.11 & 0.15 & 0.14 & 0.13 & 0.004 & $<0.05$ & ns & $<0.01$ \\
\hline Spleen & 0.04 & 0.06 & 0.06 & 0.07 & 0.02 & $<0.05$ & $<0.01$ & 0.3310 \\
\hline Liver & 0.40 & 0.51 & 0.61 & 0.57 & 0.00 & $<0.05$ & $<0.01$ & $<0.05$ \\
\hline Pancreas & 0.04 & 0.05 & 0.06 & 0.06 & 0.00 & ns & ns & ns \\
\hline Kidneys & 0.078 & 0.098 & 0.103 & 0.098 & 0.02 & $<0.05$ & $<0.01$ & $<0.01$ \\
\hline Rumen & 0.608 & 0.681 & 0.654 & 0,535 & 0.01 & ns & ns & $<0.01$ \\
\hline Reticulum & 0.109 & 0.127 & 0.115 & 0,120 & 0.01 & ns & ns & ns \\
\hline Omasum & 0.069 & 0.099 & 0.079 & 0,071 & 0.00 & $<0.05$ & ns & $<0.01$ \\
\hline Abomasum & 0.101 & 0.130 & 0.111 & 0,101 & 0.04 & ns & ns & ns \\
\hline Small intestine & 0.654 & 0.682 & 0.740 & 0,695 & 0.02 & ns & ns & ns \\
\hline Large intestine & 0.300 & 0.330 & 0.315 & 0.346 & 0.06 & ns & ns & ns \\
\hline Blood & 1.066 & 1.289 & 1.374 & 1.259 & 0.11 & $<0.05$ & $<0.05$ & $<0.01$ \\
\hline Skin & 1.706 & 2.335 & 2.643 & 2.376 & 0.02 & $<0.05$ & $<0.01$ & $<0.01$ \\
\hline Feet & 0.724 & 0.819 & 0.851 & 0.868 & 0.05 & ns & $<0.01$ & ns \\
\hline Head & 1.592 & 1.817 & 1.842 & 1.756 & 0.14 & $<0.05$ & ns & $<0.01$ \\
\hline Internal fat & 0.742 & 1.393 & 1.179 & 0.868 & 0.004 & $<0.05$ & ns & $<0.01$ \\
\hline
\end{tabular}

A: control (0 $\mathrm{g} / \mathrm{kg}$ spineless cactus) versus treatments that contained spineless cactus, B: linear effect of spineless cactus inclusion, C: quadratic effect of spineless cactus inclusion

The empty body weight of the lambs had quadratic response to the inclusion of the spineless cactus in the diet possibly because the intake of metabolisable energy and digestible protein of the animals was also quadratic. The greater energy and protein supply provided by the diet increased the flow of nutrients for the deposition of carcass and other components in the animals' EBW. Cardoso et al. (2019) found that the 
inclusion of up to $450 \mathrm{~g} / \mathrm{kg}$ of spineless cactus increased the flow of glucose and microbial protein synthesis in lamb linearly.

A quadratic effect of the dietary level of spineless cactus was observed for CCW with up to $500 \mathrm{~g} / \mathrm{kg}$ spineless cactus in the diet producing higher CCW of the animals. Thus, spineless cactus could possibly provide up to half of the DM fed to lambs being fattened in confinement. This value $-500 \mathrm{~g} / \mathrm{kg}$ - was recommended by Knupp et al. (2019) to optimise dry matter intake and weight gain of lambs fed on spineless cactus. The CCY was also increased by the inclusion of spineless cactus.

By inference, the linear reduction in gut fill and increased $\mathrm{CCl}$ are associated with the rise in the CCY. The decreased gut fill was believed to be because of the increased rate of digestion of ruminal dry matter from the feeding of spineless cactus (Siqueira et al., 2017). The increase in CCl reflected an increase in muscle mass of the carcasses, mainly in the shoulder and leg (Silva et al., 2019).

All meat cuts had quadratic responses following those of EBW and the carcass weight variables. Oliveira et al. (2018) also found quadratic effects to the inclusion of spineless cactus on the weights of the leg, shoulder, loin and belly. The meat cuts of the carcass grow at the same speed as the EBW of fattening lambs (Furusho-Garcia et al., 2006). However, no effects of the dietary inclusion of spineless cactus on the proportions of shoulder $(19.92 \% \pm 0.37)$, neck $(9.90 \% \pm 0.21)$, rib $(16.55 \% \pm 0.62)$, belly $(11.40 \% \pm 0.43)$, and leg $(34.12 \% \pm 0.51)$ were observed in the present study, possibly because of the similarity in physiological maturity of the lambs at the time of slaughter (Bonvillani et al., 2010).

The inclusion of spineless cactus in the diet resulted in quadratic effects on the weights of muscle, fat, and bone. Thus, the inclusion of 420 to $450 \mathrm{~g} / \mathrm{kg}$ of spineless cactus in the diet generated more muscular greasy carcasses with lighter bones, that is, carcasses with more edible tissues. Moura et al. (2020) also observed a decrease in the proportion of bones and an increase in the proportion of leg fat as the dietary level of spineless cactus fed to sheep increased. Specifically for adipose tissue, which in deposited later in the leg of fattening sheep Oliveira et al. (2018) the inclusion of spineless cactus had a quadratic influence on the proportion of fat, particularly adipose tissue. Blanco et al. (2012) also found that the proportion of fat in the lambs' shoulder increased with an increment in CCW, similar to the authors' observation in the present study.

Increasing the contribution of spineless cactus to the diet did not influence the $\mathrm{pH}$, tenderness, water retention and colour (lightness and redness), parameters of the meat. Possibly the similarity in the pH values $(4.84 \pm 0.17)$ of the meat provided a similar physical-chemical environment for fibrillar proteins, without effects on lightness $(37.72 \pm 0.72)$, redness $(13.63 \pm 0.44)$, shear force $(15.69 \pm 0.70)$, and WHC of the meat (33.69 \pm 0.54$)$. Abreu et al. (2019) did not verify the effect of the inclusion of spineless cactus on the $\mathrm{pH}$, colour, shear force and WHC of lamb meat. Yellowness $\left(b^{*}\right)$, however, was influenced by the inclusion of spineless cactus. Thus, the increase in the yellowness $\left(b^{*}\right)$ of the meat may be related to the increase in the intramuscular fat content of the meat of the lambs. Oliveira et al. (2019) also found quadratic performance for marbling and the $b^{*}$ of goat meat fed dehydrated spineless cactus in the diet.

There was a linear increase in the intramuscular fat content of lambs' meat with rising levels of spineless cactus. Possibly the greater energy supplied by the diets with intermediate amounts of spineless cactus, as reflected in the ME content of the diets, resulted in greater fatty acid synthesis in muscle adipocytes, which has been associated with increases in the levels of propionate and rumen butyrate (Lins et al., 2016). Plasma glucose is the main precursor of fatty acids in ruminant intramuscular adipocytes (Laliotis et al., 2010). Its level has been reported to increase with the inclusion of spineless cactus in the diet (Maciel et al., 2019; Cardoso et al., 2019).

The increase in the energy level in the diet could be responsible for the increase in the weights of the heart, liver, and kidneys of the lambs fed with spineless cactus. Ribeiro et al. (2017) reported an increase in the weight of the heart, liver, and kidneys of lambs with the inclusion of spineless cactus in the diet. These organs are a priority in the metabolism of animals and grow according to the energy level of the diet. Garcia et al. (2014) found that the organs grew faster than the EBW of growing lambs. Santos-Cruz et al. (2009) also found a positive allometric relationship between EBW and the weight of viscera and by-products of the slaughter of the lambs in fattening. Thus, the effects observed in the present study for blood, skin, feet, head and internal fat weights are because of the observed increases in EBW of lambs fed with rising levels of inclusion of spineless cactus. Oliveira et al. (2018) also found a quadratic effect of the inclusion of spineless cactus on the weight of the internal fat of lambs.

\section{Conclusion}

Inclusion of spineless cactus influenced slaughter bodyweight, carcass weight and yield, leg tissue composition and lamb meat chemical composition with the best performance for many traits being obtained 
when feeding less than $753 \mathrm{~g} / \mathrm{kg}$. It is therefore acceptable to include $500 \mathrm{~g} / \mathrm{kg}$ of spineless cactus in the diet of confined lambs as an alternative source of forage.

\section{Acknowledgements}

The authors thank the Foundation for Research Support of the State of Pernambuco (FACEPE) and the National Council for Scientific and Technological Development (CNPq) for funding the research; and the Coordination of Improvement of Personnel for Higher Education (CAPES) for the doctoral degree scholarship.

\section{Authors' Contributions}

SBLB (ORCID 0000-0003-2267-5327), DBC (ORCID 0000-0002-7137-534X) and MVM (ORCID 0000-0002-6483224X) participated in designing the study, laboratory analysis, and manuscript writing. RMLV (ORCID 0000-0003-00819596), AMVB (ORCID 0000-0001-6133-2795) and AG (ORCID 0000-0002-6589-9104) were involved in drafting and revising the manuscript for intellectual content. FFRC (ORCID 0000-0001-9211-0263), DMLJ (ORCID 0000-0002-11548579) and MVM carried out data analysis and interpretation and were involved in the preparation and revision of the manuscript. FFRC, SBLB, DMLJ contributed to the acquisition, analysis and interpretation of data.

\section{Conflict of Interest Declaration}

The authors declare that they have no conflict of interest.

\section{References}

Abreu, K.S.F., Véras, A.S.C., Ferreira, M.A., Madruga, M.S., Maciel, M.I.S., Félix, S.C.R., Vasco, A.C.C.M. \& Urbano, S.A., 2019. Quality of meat from sheep fed diets containing spineless cactus (Nopalea cochenillifera Salm Dyck). Meat Sci. 148, 229-235. https://doi.org/10.1016/j.meatsci.2018.04.036

AOAC, 2000. Official methods of analysis of AOAC International. 15th edition. AOAC International, Arlington, VA.

Batista, A.M.V., Ribeiro Neto, A.C., Lucena, R.B., Santos, D.C., Dubeux, J.C.B. \& Mustafa, A.F., 2009. Chemical composition and ruminal degradability of spineless cactus grown in northeastern Brazil. Rang. Ecology Manag. 62, 297-301. https://doi.org/10.2111/07-099R1.1

Bezerra, S.B.L., Veras, A.S.C., Silva, D.K.A., Ferreira, M.A., Pereira, K.P., Almeida, J.S. \& Santos, J.C.A., 2010. Noncarcass components of Caatinga grazing- fed goats. Pesq. Agropec. Bras. 45, 751-757.

Blanco, M.A., Panea, B.A. \& Joy, M.A., 2012. The effect of carcass weight on fatness and muscle and fat colour of male Ojinegra de Teruel light lambs. Anim. Prod. Sci. 59, 1168-1175. DOI: 10.1071/AN17903

Bonvillani, A., Peña, F., Gea, G., Gómez, G., Petryna, A. \& Perea, J., 2010. Carcass characteristics of Criollo Cordobés kid goats under an extensive management system: Effects of gender and liveweight at slaughter. Meat Sci. 86, 651-659. https://doi.org/10.1016/j.meatsci.2010.05.018

Brasil, Ministério Pecuária e Abastecimento. 2000. Instrução Normativa no 3 de 17 de Janeiro de 2000. Aprova o Regulamento técnico de métodos de insensibilização para o abate humanitário de animais de açougue. (D.O.U. 24/01/2000).

Cardoso, D.B., Carvalho, F.F.R., Medeiros, G.R., Guim, A., Cabral, A.M.D., Véras, R.M.L., Santos, K.C., Dantas, L.C.N. \& Nascimento, A.G.O., 2019. Levels of inclusion of spineless cactus (Nopalea cochenillifera Salm Dyck) in the diet of lambs. Anim. Feed Sci. Technol. 247, 23-31. https://doi.org/10.1016/j.anifeedsci.2018.10.016

Cezar, M.F. \& Sousa, W.H., 2007. Sheep and goat carcasses: Obtaining, evaluating and classifying. 1st edition.: Agropecuária Tropical, Uberaba-MG.

Duckett, S.K., Klein, T.A., Leckie, R.K., Thorngate, J.H., Busboom, J.R. \& Snowder, G.D., 1998. Effect of freezing on calpastatin activity and tenderness of callipyge lamb. J. Anim. Sci. 76, 1869-74. DOI: 10.2527/1998.7671869x

Furusho-Garcia, I.F., Perez, J.R.O., Bonagurio, S. \& Santos, C.L., 2006. Alometric study of cuts and tissues of the carcass of purebred and crossbred Santa Inês lambs. R. Bras. Zootec. 35,1416-1422. https://doi.org/10.1590/S1516-35982006000500022

Furusho-Garcia, I.F., Perez, J.R.O., Pereira, I.G., Costa, T.I.R. \& Martins, M.O., 2009. Allometric study on carcass tissues from purebred Santa Inês lambs or crossbred with Texel, lle de France and Bergamácia. R. Bras. Zootec. 38, 539-546. https://doi.org/10.1590/S1516-35982009000300020

Garcia, I.F.F., Alvarenga, T.I.R.C., Perez, J.R.O., Almeida, A.K., Gallo, S.B., Pereira, I.G., Alves, N.G. \& Alvarenga, F.A.P., 2014. Allometric growth of non-carcass components in crossed lambs. Cie. Rural, 44, 1229-1235. http://dx.doi.org/10.1590/0103-8478cr20130489.

Gonzaga Neto, S., Silva Sobrinho, A.G., Zeola, N.M.B.L., Marques, C.A.T., Silva, A.M.A., Pereira Filho, J.M. \& Ferreira, A.C.D., 2006. Características quantitativas da carcaça de cordeiros deslanados Morada Nova em função da relação volumoso:concentrado na dieta. R. Bras. Zootec. 35, 1487-1495. https://doi.org/10.1590/S151635982006000500031

Hall, M.B., 2000. Calculation of non-structural carbohydrate content of feeds that contain non-protein nitrogen. University of Florida, Gainesville.

Knupp, L.S., Carvalho, F.F.R., Cannas, A., Marcondes, M.I., Silva, A.L., Francesconi, A.H.D., Cruz, G.R.B., Atzori, A.S., Gaspa, G. \& Costa, R.G., 2019. Meta-analysis of spineless cactus feeding to meat lambs: performance and development of mathematical models to predict dry matter intake and average daily gain. Animal 13, 2260-2267. https://doi.org/10.1017/S1751731119000326

Laliotis, G.P., Bizelis, I. \& Rogdakis, E., 2010. Comparative approach of the de novo fatty acid synthesis (lipogenesis) 
between ruminant and non ruminant mammalian species: From biochemical level to the main regulatory lipogenic genes. Curr. Genomics 11, 168-183. DOI: 10.2174/138920210791110960

Licitra, G., Hernandez, T.M. \& Van Soest, P.J., 1996. Standardization of procedures for nitrogen fractionation of ruminant feed. Anim. Feed Sci. Technol. 57, 347-358. https://doi.org/10.1016/0377-8401(95)00837-3

Lins, S.E.B., Pessoa, R.A.S., Ferreira, M.A., Campos, J.M., Silva, J.A., Silva, J.L., Santos, A.S. \& Melo, T.T.B., 2016. Spineless cactus as a replacement for wheat bran in sugar cane-based diets for sheep: intake, digestibility, and ruminal parameters. R. Bras. Zootec. 45, 26-31. https://doi.org/10.1590/S1806-92902016000100004

Maciel, L.P.A.A., Carvalho, F.F.R., Batista, A.M.V., Guim, A., Maciel, M.V., Cardoso, D.B. \& Lima Júnior, D.M., 2019. Intake, digestibility and metabolism in sheep fed with rising levels of spineless cactus (Nopalea cochenillifera Salm Dyck). Trop. Anim. Health Prod. 51, 1717-1723. DOI: 10.1007/s11250-019-01868-4

Moura, M.S.C., Guim, A., Batista, Â.M.V., Maciel, M.V., Cardoso, D.B., Lima Júnior, D.M. \& Carvalho, F.F.R., 2020. The inclusion of spineless cactus in the diet of lambs increases fattening of the carcass. Meat Sci. 160, 107975. https://doi.org/10.1016/j.meatsci.2019.107975

NRC., 2007. Nutrient Requirements of small ruminants: Sheep, goats, cervids, and New World camelids. 1st edition. National Academy of Science, Washington DC.

Oliveira, F.A., Carvalho, G.G.P., Assis, D.Y.C., Oliveira, R.J.F., Nascimento, C.O., Tosto, M.S.L. \& Pina, D.S., 2019. Quantitative and qualitative traits of carcass and meat of goats fed diets with cactus meal replacing corn. Trop. Anim. Health Prod. 51, 589-598. DOI: 10.1007/s11250-018-1733-1

Oliveira, J.P.F., Ferreira, M.A., Alves, A.M.S.V., Melo, A.C.C., Andrade, I.B., Urbano, S.A., Suassuna, J.M.A., Barros, L.J.A. \& Melo, T.T.B., 2018. Carcass characteristics of lambs fed spineless cactus as a replacement for sugarcane. Asian-Austral. J. Anim. Sci. 31, 529-536. DOI: 10.5713/ajas.17.0375

Purchas, R.W., Davies, A.S. \& Abdullah, A.Y., 1991. An objective measure of muscularity: changes with animal growth and differences between genetic lines of Southdown sheep. Meat Sci. 30, 81-94. https://doi.org/10.1016/03091740(91)90037-Q

Ramos, E.M. \& Gomide, L.A.M., 2009. Meat quality assessment: Fundamentals and methodologies. 2nd edition. UFV:MG, Brazil.

Ribeiro, J.S., Santos, L.L., Lima Júnior, D.M., Mariz, T.M.A., Ladeira, M.M., Azevedo, P.S., Lima, C.B. \& Silva, M.J.M.S., 2017. Spineless cactus associated with Tifton hay or sugarcane bagasse may replace corn silage in sheep diets. Trop. Anim. Health Prod. 49, 995-1000. DOI: 10.1007/s11250-017-1288-6

Salem, H.B., 2010. Nutritional management to improve sheep and goat performances in semiarid regions. R. Bras. Zootec. 39, 337-347. https://doi.org/10.1590/S1516-35982010001300037

Santos-Cruz, C.L., Pérez, J.R.O., Muniz, J.A., Cruz, C.A.C. \& Vasconcelos, T.R.A., 2009. Development of live weight components from Santa Inês and Bergamácia lambs slaughtered at different weights. R. Bras. Zootec. 38, 923932. https://doi.org/10.1590/S1516-35982009000500020

Sierra, I., 1973. Statistics from the creative studio Blanco Belga x Landrace: Productive characters, channel quality and meat quality. Instituto de Economía y Producciones Ganaderas del Ebro, Zaragoza. 16:43.

Silva, T.G.P., Batista, Â.M.V., Guim, A., Silva, V.A., Carvalho, F.F.R., Barros, M.E.G., Sousa, D.R. \& Silva, S.M.C., 2020. Histomorphometric changes of the fore-stomach of lambs fed with diets containing spineless cactus genotypes resistant to Dactylopius sp. Trop. Anim. Health Prod. 52, 1299-1307. DOI: 10.1007/s11250-019-02129-0.

Siqueira, M.C.B., Ferreira, M.A., Monnerat, J.P.I.S., Silva, J.L., Costa, C.T.F., Conceição, M.G., Andrade, R.P.X., Barros, L.J.A. \& Melo, T.T.B., 2017. Optimizing the use of spineless cactus in the diets of cattle: Total and partial digestibility, fibre dynamics and ruminal parameters. Anim. Feed Sci. Technol. 226, 56-64. https://doi.org/10.1016/j.anifeedsci.2016.12.006

Van Soest, P.J., Robertson, J.B. \& Lewis, B.A., 1991. Methods for dietary fibre, neutral detergent fibre, and non starch polysaccharides in relation to animal nutrition. J. Dairy Sci. 74, 3583-3597. https://doi.org/10.3168/jds.S00220302(91)78551-2 